\title{
In situ hybridization demonstrates that Litopenaeus vannamei, L. stylirostris and Penaeus monodon are susceptible to experimental infection with infectious myonecrosis virus (IMNV)
}

\author{
Kathy F. J. Tang*, Carlos R. Pantoja, Bonnie T. Poulos, Rita M. Redman, \\ Donald V. Lightnere
}

Department of Veterinary Science and Microbiology, University of Arizona, Tucson, Arizona 85721, USA

\begin{abstract}
Infectious myonecrosis virus (IMNV) was recently found to be the cause of necrosis in the skeletal muscle of farm-reared Litopenaeus vannamei from northeastern Brazil. Nucleic acid extracted from semi-purified IMN virions showed that this virus contains a $7.5 \mathrm{~kb}$ RNA genome. A cDNA library was constructed, and a clone, designated as IMNV-317, was labeled with digoxigenin11-dUTP and used as a gene probe for in situ hybridization (ISH). This probe specifically detected IMNV in infected tissues. To determine the susceptibility of 3 species of penaeid shrimp ( $L$. vannamei, L. stylirostris, Penaeus monodon) to IMNV infection, juveniles were injected with purified virions and observed for clinical signs of infection and mortality over a 4 wk period. All $L$. vannamei exhibited typical lesions after $6 \mathrm{~d}$, and lesions were visible in all L. stylirostris by Day 13. The clinical signs of opaque muscle were not seen in P. monodon, due to their highly pigmented exoskeleton precluding visual detection of lesions. Moderate mortality $(20 \%)$ occurred in infected $L$. vannamei. No mortalities were observed in either L. stylirostris or P. monodon. Histological examination and ISH indicated that all 3 species are susceptible to IMNV infection. Using ISH, IMNV was detected in tissues including the skeletal muscle, lymphoid organ, hindgut, and phagocytic cells within the hepatopancreas and heart. In all 3 species, skeletal muscle cells produced the strongest ISH reactions. Based on the onset of clinical signs of infection and mortality, L. vannamei appears to be the most susceptible of these 3 species to IMNV infection.
\end{abstract}

KEY WORDS: Infectious myonecrosis virus · IMNV $\cdot$ In situ hybridization · Penaeid shrimp

\section{INTRODUCTION}

Infectious myonecrosis virus (IMNV) was first discovered in 2003 in diseased Litopenaeus vannamei cultured in Brazil (D. V. Lightner et al. unpubl. data). This virus infects, and causes multifocal to diffuse necrosis in, skeletal muscle. The major clinical sign is the appearance of whitish, opaque lesions in the skeletal muscle, and infected shrimp eventually become lethargic. Infection can cause 40 to $60 \%$ mortality in affected ponds, and the economic loss in Brazil due to this disease was estimated to be US\$20 million in 2003 (Nunes et al. 2004).

Current methods for diagnosis of IMNV infection rely on clinical signs and histological examination. These methods are, however, not adequate for diagnosis, since a number of factors (e.g. hypoxia, crowding, or sudden changes in temperature or salinity) can cause similar signs (Lightner 1988). In contrast, in situ hybridization (ISH) is both specific and sensitive, and 
thus applied routinely for the diagnosis of several shrimp viruses (Durand et al. 1996, Mari et al. 1998, Tang \& Lightner 1999).

Live Litopenaeus vannamei are frequently exported to areas where this species is not indigenous. It is, therefore, prudent to determine the susceptibility of other species of penaeid shrimp to IMNV, particularly the farmed species L. stylirostris and Penaeus monodon. Thus, we report experimental infections with these 3 species of penaeid shrimp to determine their susceptibility to IMNV.

\section{MATERIALS AND METHODS}

IMNV used in this study was isolated from farmraised Litopenaeus vannamei obtained from Brazil in 2003 and stored at $-70^{\circ} \mathrm{C}$ at the University of Arizona, USA. A preparation of semi-purified virions was made from the tail muscle of infected shrimp. Infected tissue was minced, homogenized in TN buffer (10 mM Tris$\mathrm{HCl}, \mathrm{pH} 7.4,400 \mathrm{mM} \mathrm{NaCl}$ ), and clarified at $2987 \times g$ for $20 \mathrm{~min}$ in a Sorval RC-5B centrifuge. The supernatant was ultracentrifuged at $205000 \times g$ for $3 \mathrm{~h}$ in a Sorval TH641 rotor. The resulting pellet was suspended in TN buffer and total RNA was extracted using the TRIzol reagent (Invitrogen) in accordance with the manufacturer's protocol. Purified RNA was resuspended in DEPC (diethylpyrocarbonate)-treated water and was subjected to electrophoresis in a $1 \%$ (w/v) non-denaturing agarose gel containing ethidium bromide. A high molecular weight ( 7.5 kb) band was excised from the gel and purified using a QIAQuick gel extraction kit (Qiagen). This nucleic acid was treated with either RNase A $\left(10 \mu \mathrm{g} \mathrm{ml}^{-1}\right.$ in $10 \mathrm{mM}$ Tris$\mathrm{HCl}, \mathrm{pH} 7.5,15 \mathrm{mM} \mathrm{NaCl})$ or DNase I $\left(5 \mu \mathrm{g} \mathrm{ml}^{-1}\right)$ for $30 \mathrm{~min}$ at $37^{\circ} \mathrm{C}$.

cDNA was synthesized using the SuperScript Choice system (Invitrogen) and ligated into pSport 1 plasmid in accordance with the procedures described by Tang \& Lightner (1999). Prior to cDNA synthesis, the RNA was boiled for 2 min, and quickly chilled on ice. The recombinant plasmids were transformed into competent Escherichia coli DH5a cells using standard procedures, and clones containing cDNA inserts were selected by colony-PCR using the primers M13F (5'GTTTTCCCAGTCACGAC-3') and M13R (5'-CAGGA AACAGCTATGAC-3'). PCR amplicons were purified and then sequenced using an automatic DNA sequencer, ABI Prism 377 (Applied Biosystems) at the University of Arizona sequencing facility. Sequencing of PCR amplicons from cDNA clones has allowed determination of the complete $7560 \mathrm{bp}$ genomic sequence of IMNV (D. V. Lightner et al. unpubl. data).
The DNA probe used in the ISH was prepared from cDNA clone IMNV-317 by PCR labeling with digoxigenin-11-dUTP as described by Mari et al. (1998). The primers used in the labeling reaction were IMNV993F (5'-AACACAAAATCTGCCAGCAA-3') and IMNV 993R (5'-CCCAACCACCCAAATTCATA-3') and they generated a $993 \mathrm{bp}$ amplicon. Following polymerase chain reaction (PCR), the digoxigenin-labeled DNA probe was precipitated with ethanol, re-suspended in water, and stored at $-20^{\circ} \mathrm{C}$.

Three species (Litopenaeus vannamei, L. stylirostris, Penaeus monodon) of penaeid shrimp were used for infectivity studies. Seven individuals of each species (mean weight: $3 \mathrm{~g}$ ) were injected with purified IMN virions prepared from the tail muscle of infected shrimp (D. V. Lightner et al. unpubl. data). Each shrimp was injected with $100 \mu$ of inoculum. Shrimp were maintained on a pelletized ration for $4 \mathrm{wk}$. On Day 14 post-injection, 1 shrimp of each species was sampled for histological examination and ISH. At the end of the bioassay, surviving shrimp were fixed in Davidson's fixative. For per os infection of $L$. vannamei, 25 shrimp (mean weight: $3.5 \mathrm{~g}$ ) were fed minced IMNV-infected shrimp tissues at $6 \%$ of body weight for $3 \mathrm{~d}$, followed by a pelletized ration for $4 \mathrm{wk}$.

The fixed shrimp were processed, embedded in paraffin, and sectioned ( $4 \mu \mathrm{m}$ thick) in accordance with standard methods. Procedures used for hematoxylin and eosin (H\&E) staining and ISH were as described by Lightner (1996). For ISH, the sections on slides were overlaid with $500 \mu \mathrm{l}$ of hybridization solution (4 SSC, $50 \%(\mathrm{v} / \mathrm{v})$ formamide, 1 Denhard's, $5 \%$ (w/v) dextran sulfate, $0.5 \mu \mathrm{g} \mathrm{ml}^{-1}$ salmon sperm DNA) containing IMNV probe $\left(0.2 \mu \mathrm{g} \mathrm{ml}^{-1}\right)$. Slides were placed on a heated surface at $84^{\circ} \mathrm{C}$ for $10 \mathrm{~min}$, chilled on the ice for $2 \mathrm{~min}$, and incubated overnight in a hybridization oven at $42^{\circ} \mathrm{C}$. Final color development was performed with anti-digoxigenin antibody conjugated to alkaline phosphatase and nitroblue tetrazolium and 5-bromo-4chloro-3-indoyl phosphate (Mari et al. 1998).

\section{RESULTS AND DISCUSSION}

The IMNV genome was determined to be RNA by enzymatic reactions. Infection with IMNV results in the formation of inclusion bodies that are localized in the cytoplasm, a common characteristic of most RNA virus infections. Purified IMN virions were found to be $40 \mathrm{~nm}$ diameter icosahedrons with a buoyant density of only $1.369 \mathrm{~g} \mathrm{ml}^{-1}$ (D. V. Lightner et al. unpubl. data). Electrophoresis of RNA extracted from a semi-purified viral preparation identified a $\sim 7.5 \mathrm{~kb}$ band that was digested completely by RNase A but not by DNase 1 (Fig. 1). In the agarose gel containing ethidium 


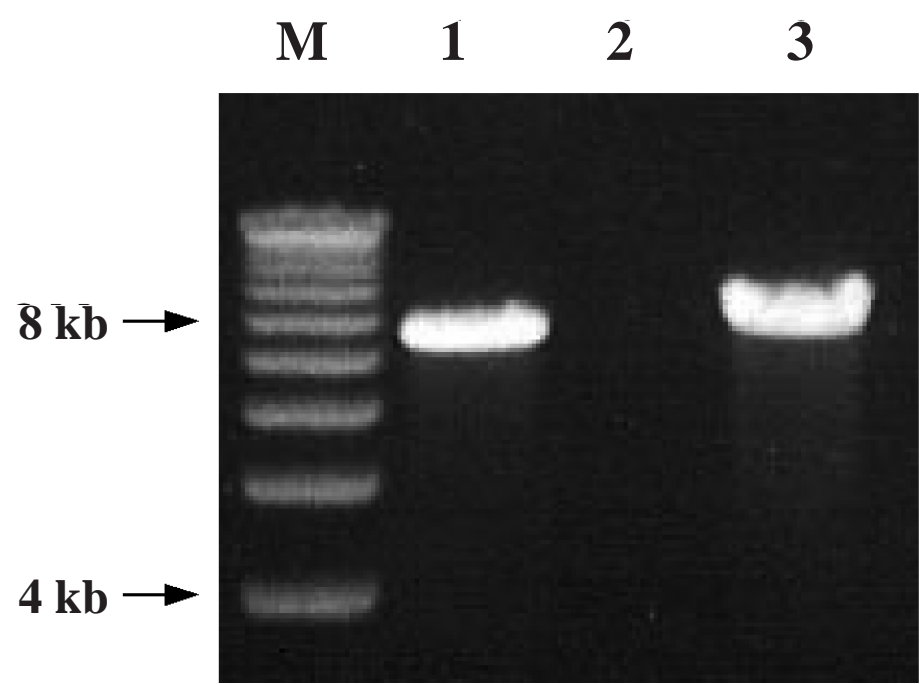

Fig. 1. Isolation of infectious myonecrosis virus (IMNV) RNA. Lane M: $1 \mathrm{~kb}$ DNA ladder; Lane 1: RNA extracted from semipurified IMNV virions; the extracted RNA was digested with RNase A (Lane 2) and with DNase 1 (Lane 3) bromide, this band was bright, suggesting that the viral RNA is double-stranded.

In order to obtain a probe for ISH, a cDNA library was constructed and a cDNA clone containing a $1257 \mathrm{bp}$ viral insert was selected. The sequence of this insert corresponds to the 2601 to 3857 nucleotide region of the IMNV genome and is located within the capsid protein-coding sequence. A pair of primers designed from sequence within this insert was used to prepare a 993 bp digoxigenin-labeled probe by PCR.

To detect dsRNA in tissue by ISH, the dsRNA must first be denatured to separate the strands and allow them to hybridize to the probe. A strong ISH signal was observed in tissue sections that were denatured at $84^{\circ} \mathrm{C}$ for $10 \mathrm{~min}$, while either no signal or only a faint signal occurred when this step was omitted.

The ISH probe was used to detect Litopenaeus vannamei tissues infected with IMNV. Skeletal muscle showed the most pronounced ISH signal. The H\&E stained section showed single and clusters of multiple basophilic inclusion bodies present in the cytoplasm and adjacent to the nucleus (Fig. 2A). These inclusions
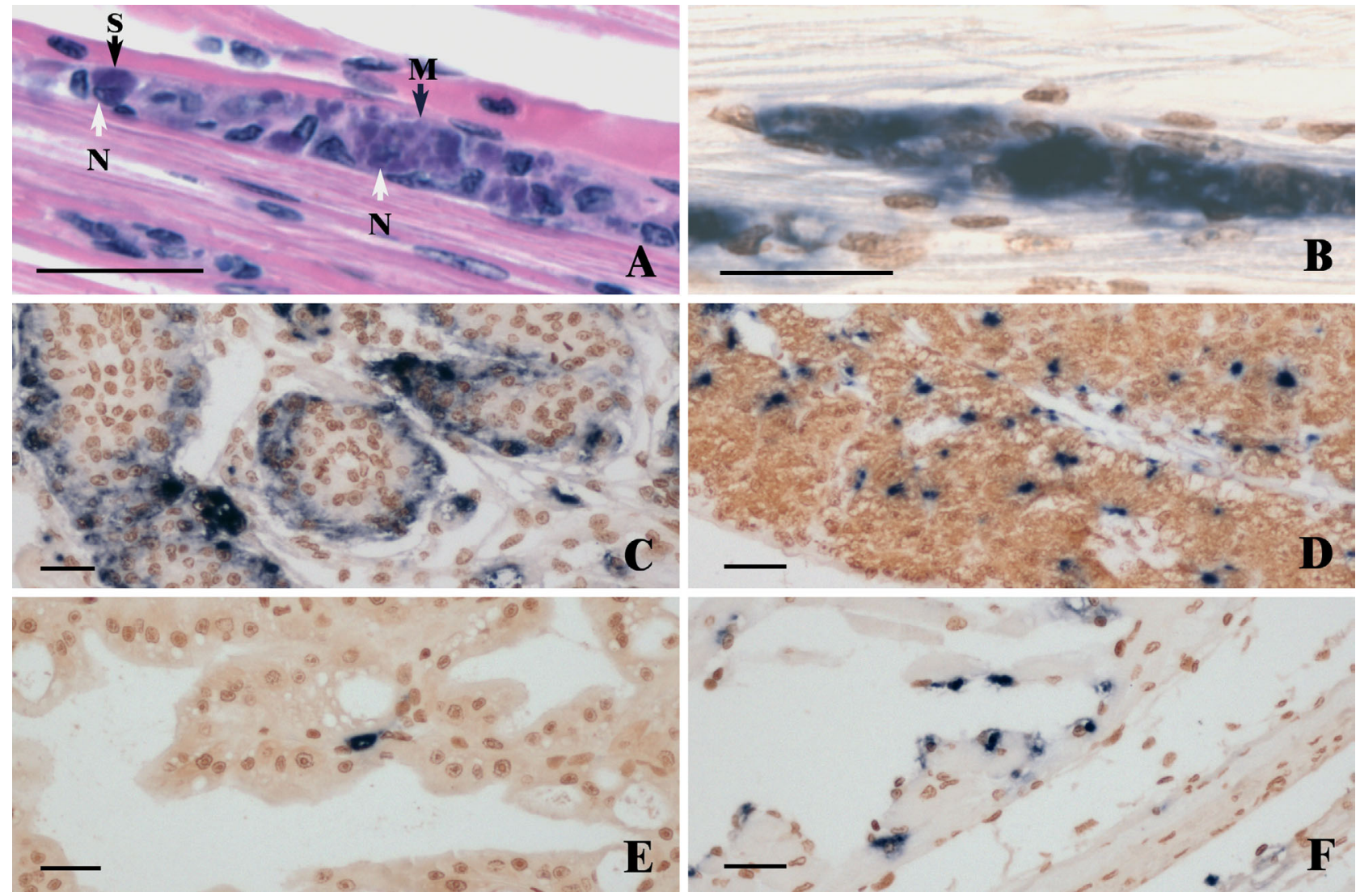

Fig. 2. Litopenaeus vannamei. H\&E histology and in situ hybridization detection of IMNV in infected shrimp. (A) H\&E staining of skeletal muscle; arrows indicate nucleus (N), single (S) and multiple (M) inclusions. (B) In situ hybridization of the serial section with a digoxigenin-labeled IMNV probe. In situ detection of IMNV in (C) lymphoid organ, (D) hindgut, (E) hepatopancreas, and (F) heart. Scale bars $=25 \mu \mathrm{m}$ 
reacted intensely with the probe (Fig. 2B). No reaction was seen in any of the tissues prepared from healthy, uninfected shrimp or from those infected with white spot syndrome virus (WSSV), infectious hypodermal and hematopoietic necrosis virus (IHHNV), Taura syndrome virus (TSV), or yellow head virus (YHV) (data not shown).

To determine their susceptibility to IMNV, 3 species of penaeid shrimp were injected with an inoculum containing purified virions. The major clinical sign of infection, the appearance of whitish lesions in the tail muscle, was first seen in Litopenaeus vannamei (Table 1). All 7 injected shrimp had obvious lesions after 6 d. In L. stylirostris, the lesions developed slowly, with 3 out 7 shrimp showing signs of infection after $7 d$, and all had lesions after $13 \mathrm{~d}$. No clinical signs of infection were observed in Penaeus monodon during the 4 wk bioassay period. However, the lack of clinical signs was due to the highly pigmented exoskeleton of this species obscuring the lesions. On Day 14 postinjection, 1 shrimp from each species was sacrificed and processed for histological examination and ISH, and they were positive for IMNV infection.

In Litopenaeus vannamei, the first mortality was noted at Day 13, and only 1 other of the remaining 5 shrimp died before the end of the bioassay. No mortalities occurred in L. stylirostris and P. monodon during the 4 wk period. In ponds, IMNV may be spread through cannibalism. Thus, another group of $25 \mathrm{~L}$. vannamei was challenged by feeding infected shrimp tissues. Clinical signs of infection appeared after $9 \mathrm{~d}$, and 5 out of the $25(20 \%)$ shrimp died by the end of the bioassay.

Histological examination confirmed that shrimp of each species were infected with IMNV, as evidenced

Table 1. Time of appearance of clinical signs of infection and mortality in 3 species of penaeid shrimp after injection of infectious myonecrosis virus (IMNV), anddetection of IMNV infection by histology and in situ hybridization (ISH)

\begin{tabular}{|lcccc|}
\hline Species & $\begin{array}{c}\text { Day of } \\
\text { apearance } \\
\text { of clinical } \\
\text { signs }{ }^{\mathrm{a}}\end{array}$ & $\begin{array}{c}\text { Day of initial } \\
\text { death }\end{array}$ & No. dead & $\begin{array}{c}\text { IMNV }^{\mathrm{b}} \\
\text { infection }\end{array}$ \\
\hline $\begin{array}{l}\text { Litopenaeus } \\
\text { vannamei } \\
\text { Litopenaeus } \\
\text { stylirostris }\end{array}$ & 6 & 13 & $2 / 6$ & Positive \\
$\begin{array}{l}\text { Penaeus } \\
\text { monodon }\end{array}$ & No signs ${ }^{\mathrm{c}}$ & No death & $0 / 6$ & Positive \\
& No death & $0 / 6$ & \\
$\begin{array}{l}\text { a Days after injection when all the shrimp showed clinical signs } \\
\text { 'Determined by both H\&E and ISH }\end{array}$ & \\
\hline
\end{tabular}

by lesions in skeletal muscle including multifocal necrosis, hemocytic congestion, fibrocytic inflammation, phagocytosis, and the appearance of cytoplasmic inclusion bodies. Formation of lymphoid organ spheroids was also observed in each species. ISH confirmed this finding, and positive signals were cytoplasmic and especially intense in the skeletal muscle. The signals were also localized within focal areas, suggesting that the virus did not readily spread to neighboring muscle bundles. In Litopenaeus vannamei, and similarly in $L$. stylirostris, the reacting tissues included skeletal muscle (Fig. 2B), lymphoid organ (both normal tubules and spheroids), hindgut, and the phagocytic cells within the hepatopancreas and heart (Fig. 2C-F). In Penaeus monodon, in addition to the ISH-positive tissues found in L. vannamei, the probe reacted in the gills. The tissues that were ISH negative for IMNV in all species included the stomach, ventral nerve cord, ganglia, and hematopoietic organs.

We describe the development of an ISH test for definitive diagnosis of IMNV infection in histological sections. The ISH results associated IMNV infection with lesions detected by histology. However, ISH was more sensitive; tissues with no visible signs of infection by histological examination were found to be infected when tested with the probe. Further, the probe provides needed specificity, for example, in recent diagnostic samples received by our lab, muscle necrosis in Litopenaeus vannamei (from Belize) and Penaeus monodon (from Australia) was evident and suspected to be caused by IMNV. However, both were negative by ISH. This indicates that diagnosis based on gross signs and/or histology can be misleading. Thus, without the availability of the ISH test, diagnosis based on gross signs and/or histology alone can be misleading.

All 3 major species of farmed penaeid shrimp (Litopenaeus vannamei, L. stylirostris and Penaeus monodon) tested in our bioassays were susceptible to IMNV infection. L. vannamei, which IMNV narurally infects, appears to be most susceptible based on the onset of clinical signs of infection and mortality. However, IMNV is not particularly virulent compared to other shrimp viruses such as TSV, YHV and WSSV: in the bioassays described herein, no mortality occurred until 9 to $13 \mathrm{~d}$ after exposure to IMNV, while significant mortality can occur within 1 to $3 \mathrm{~d}$ in bioassays with TSV, YHV, or WSSV (Lu et al. 1994, Overstreet et al. 1997, Tang \& Lightner 2000). This observation may be related to the fact that skeletal muscle, the primary target tissue of IMNV infection, is not as vital as other tissues, and that muscle 
necrosis from other causes can be repaired at an early stage (Lightner 1988). However, the economic losses from IMNV infection can still be significant, with over $40 \%$ mortality reported to occur late in the production cycle and the potential for a reduced market value of the survivors which have necrotic tail muscles.

Acknowledgements. This work was supported by Gulf Coast Research Laboratory Consortium Marine Shrimp Farming Program, CSRS, USDA, under Grant No. 2002-38808-01345, and a special grant from the National Fishery Institute. We thank T. P. Andrade of the Brazilian Shrimp Farms Association $(\mathrm{ABCC})$ for providing the IMNV-infected shrimp samples.

\section{LITERATURE CITED}

Durand S, Lightner DV, Nunan LM, Redman RM, Mari J, Bonami JR (1996) Application of gene probes as diagnostic tools for white spot baculovirus (WSBV) of penaeid shrimp. Dis Aquat Org 27:59-66

Lightner DV (1988) Muscle necrosis of penaeid shrimp. In: Sindermann CJ, Lightner DV (eds) Disease diagnosis and control in north America marine aquaculture. Develop-

Editorial responsibility: Timothy Flegel,

Bangkok, Thailand ments in aquaculture and fisheries science, Vol 17. Elsevier Press, New York, p 122-124

Lightner DV (1996) A handbook of shrimp pathology and diagnostic procedures for diseases of cultured penaeid shrimp. World Aquaculture Society, Baton Rouge, LA

Lu Y, Tapay LM, Brock JA, Lou PC (1994) Infection of the yellow head baculo-like virus (YBV) in two species of penaeid shrimp, Penaeus stylirostris (Stimpson) and Penaeus vannamei (Boone). J Fish Dis 17:649-656

Mari J, Bonami JR, Lightner DV (1998) Taura syndrome of penaeid shrimp: cloning of viral genome fragments and development of specific gene probes. Dis Aquat Org 33: $11-17$

Nunes AJP, Martins PCC, Gesteira TCV (2004) Produtores sofrem com as mortalidades decorrentes do virus da mionecrose infeccisa (IMNV). Panorama da AQUICULTURA, Maio/Junho, p 37-51

Overstreet RM, Lightner DV, Hasson KW, McIlwain S, Lotz JM (1997) Susceptibility to Taura syndrome virus of some penaeid shrimp species native to the gulf of Mexico and the southeastern United States. J Invertebr Pathol 69:165-176

Tang KFJ, Lightner DV (1999) A yellow head virus gene probe: nucleotide sequence and application for in situ hybridization. Dis Aquat Org 35:165-173

Tang KFJ, Lightner DV (2000) Quantification of white spot syndrome virus DNA through a competitive polymerase chain reaction. Aquaculture 189:11-21

Submitted: September 6, 2004; Accepted: December 14, 2004 Proofs received from author: February 4, 2005 